\title{
ARTICLE Does Digitalization Matter for Grievance Redress Mechanism? An Analysis of the E-Government Procurement in the Local Government
}

\author{
Habibullah Mohammad Himel Shuvra Chowdhury* \\ Department of Public Administration. Faculty of Social Sciences, University of Rajshahi, Rajshahi, Bangladesh
}

\section{ARTICLE INFO}

Article history

Received: 24 December 2021

Accepted: 14 January 2022

Published Online: 18 January 2022

Keywords:

E-government procurement (e-GP)

Digitalization

Grievance-redress mechanism

General Financial Rule (GFR)

Public finance

\begin{abstract}
Public procurement denotes the attainment of goods, works, or services required by governments through contracts. Public procurement is usually plagued with covert practices and exclusive forms of corruption in Bangladesh. The cost of development finance is much higher in public procurement than that of others in Bangladesh. There have been no unified rules or laws regarding government purchases since 2006. The Government of Bangladesh enacted its ever first act of public procurement, the Public Procurement Act, 2006 (PPA, 2006), and the Public Procurement Rules, 2008 (PPR, 2008). The procurement entity must disseminate procurement information through electronic medium i.e. Electronic Government Procurement (hereinafter e-GP). Despite passing over an era since its enactment, the role of the PPA, 2006 remains seriously under-researched area, specifically there is no research on the issue of the grievance redress mechanisms. The study has been done using a qualitative case study methodology, backed by both primary and secondary documentary analysis. Based on empirical data, this paper explained the role of digitalization in the process of government procurement and depicted changes that have been brought by the implementation of e-GP in government purchases. However, it concluded that the grievance redress mechanism in the process of procurement is only existing in the policy papers which need mandatory implementation for a transparent and accountable governance system. Despite the significant changes and up-gradation in digital government procurement, it is hardly found that the GRM process is digitalized. And the mass tenderers are yet to be acquainted with the improvised system apart from the consistent efforts of the government.
\end{abstract}

design, sketch, goods, etc. is the key task. Thus, the accomplishment of the task followed by the costs associated with the concerned work is of utmost products or services in any form including construction,
For any organization-private and public-providing

\section{Introduction} products or services in any form including construction,

*Corresponding Author:

Shuvra Chowdhury,

Department of Public Administration. Faculty of Social Sciences, University of Rajshahi, Rajshahi, Bangladesh;

Email: shuvrachowdhury87@gmail.com

DOI: https://doi.org/10.30564/mmpp.v3i4.4269

Copyright (C) 2021 by the author(s). Published by Bilingual Publishing Co. This is an open access article under the Creative Commons Attribution-NonCommercial 4.0 International (CC BY-NC 4.0) License. (https://creativecommons.org/licenses/by-nc/4.0/). 
importance for the personnel involved. This should be ensured by value for money (VFM)-that we know from the paradigms of the New Public Management (NPM), the New Public Governance (NPG) to the New Public Service (NPS) ${ }^{[1]}$. The concepts of 3E's -economy, efficiency, and effectiveness should be ensured so that service delivery should not be questionable. In the 3E's concept, economy and efficiency entail the parsimony of use of resources, which means minimal use of resources and getting maximum output while effectiveness is concerned with the outcome of the effort of producing any service or product $^{[2-4]}$.

In public finance, the task of procurement is to not only purchase or deliver; it deals with politicians to be reelected following the desire of the public and the supply of resources in the budget process ${ }^{[5]}$. Public procurement entails the government purchases spending public funds to enhance public services. It is revealed that the contribution of public procurement to the Gross Domestic Production (GDP) of the countries of the European Union (EU) is up to 16 percent and according to the statistics of the World Trade Organization (WTO), globally the contribution of public procurement in GDP is between 10 and 15 percent i.e. the share of public procurement in GDP is higher in low and middle-income countries than rich countries ${ }^{[6]}$. In Bangladesh, public procurement costs much of development finance around $80 \%$ of the annual development expenditure ${ }^{[7,8]}$. Thus, it can be presumed that a transparent and efficient procurement process of a state can uphold the value of the political party in power for reelection and the morale of the administrators and justice for the voters: they are the ultimate taxpayer or in other words, source of public finance.

Before enactment of 'the Public Procurement Act, 2006' (hereafter the PPA, 2006) and 'the Public Procurement Rules, 2008' (hereafter the PPR, 2008), there have been no unified rules or laws regarding government purchases ${ }^{[9]}$. The public procurement processes were regulated through the general financial rules (GFR). Analyzing the health sector public financial management, it is argued, that general financial rule was outdated and followed weak practices for efficient formulation and implementation of budget ${ }^{[10]}$. The compilation of general financial rules is traced back to the British ruler and had been changed from time to time during the Pakistani regime of rule and by the government of Bangladesh (GoB) since $2003^{[11,12]}$. Studies revealed that contracts awarded relating to public procurement remain a great source of corruption in the Bangladeshi administration ${ }^{[7]}$.

In Bangladesh, there was no performance-based appraisal of a project or result-based management that existed in the evaluation process of a government project before the enactment of the PPA, 2006, and the PPR, 2008. In this perspective, this paper aims at evaluating the grievance redress mechanism of e-government procurement (hereinafter e-GP)- specifically the grievance redress mechanism of the tenderers at the Local Government Engineering Department (LGED) of Bangladesh.

The LGED is one of the largest public sector organizations in Bangladesh. It remains the key to unlocking the rural-level development goals. The LGED bears the responsibility of planning and implementation of infrastructures, development programs like small-scale water resources at the very rural and rural-urban levels. It works closely with the local stakeholders to ensure people's participation. It maintains bottom-up planning over the stages of the implementation cycle and runs development activities with the broad objective that is to improve the socio-economic condition of the country through the supply of infrastructure at the local level and capacity building of the stakeholders. This department promotes labor-based technologies and indigenous materials to create employment at the root level. It has a wide range of diversified development programs i.e. construction of roads, bridges/culverts, and markets for social mobilization, empowerment, and environmental protection. The LGED evolved much from time to time to its current organogram. In the early sixties, the Works Program (WP) entailed with Thana Irrigation Program (TIP), Rural Works Program (RWP), and Thana Technical Development Committee (TTDC) had been formed. In the 1970s, a "Cell" was established in the Local Government Division (LGD) under the Ministry of Local Government, Rural Development and Cooperative (MLGRD\&C). And in 1982, it was named the Works Program Wing (WPW) to administer a nationwide works program. After that, it became reformed with the name of Local Government Engineering Bureau under the revenue budget of the government in October 1984. The LGED was upgraded as the Local Government Engineering Department (LGED) in August $19922^{[13]}$. The LGED was one of the four target agencies to implement e-GP in 2011. It topped the list by inviting the highest number of tenders among all the government departments. By 2016, LGED touched the bar of $100 \%$ works procurement in e-GP. Currently, it has a total of 898 procuring entities and all are inviting works procurement tender in e-GP. LGED is also aiming at introducing an electronic contract management system (e-CMS) by 2022 through the project called the Digitizing Implementation and Public Procurement Project (DIMAPP). 


\section{Research Method}

The paper analyzed the background of the reform agenda -the legal state of the e-GP in the light of the PPA, 2006 and the PPR, 2008, followed by a conceptual understanding of digitalization and grievance redress mechanism. Based on the case-oriented qualitative research strategy, the required data of this paper have been collected using both primary and secondary sources. The primary source of data includes direct observation, key informant interviews, document review, content analysis, etc. The key informants were tenderers, bank officials, members of civil society and non-government organizations (NGOs), etc. The secondary sources of data include books, dissertations, journals, etc. Thus, a valid database exposes the changes that have been brought by the implementation of e-GP in government purchases towards the path of sustainable development and also addresses the grievance redress mechanism in this regard.

\section{Grievance Redress Management-A Con- ceptual Understanding}

On a general concept, the grievance may stand for a formal complaint against any unfair treatment. Opatha ${ }^{[14]}$ (2019) from his comprehensive analysis of literature and a systematic study found that there is no generally accepted definition of a grievance. Generally, in an organization, a formal dispute between management and employee is regarded as a grievance ${ }^{[15]}$. The Cambridge dictionary defines 'grievance' as "a complaint or a strong feeling that you have been treated unfairly." It emphasizes the human feeling of being treated unfairly. Similarly, the Collins dictionary defines 'grievance' as "grievance is about something that has happened or been done, you believe that it was unfair." Though it expresses belief instead of feelings, it makes an otherness in the definition. Unlike, Cambridge and Collins, the Business dictionary makes a clear and detailed meaning of it. It describes grievance covering two sectors i.e. law and human resources. The Business dictionary defines grievance under, "1. Law: (1) Injury, injustice, or wrong that affords a reason for resistance or a formal expression as a complaint. (2) The complaint itself. 2. Human resources: Specific complaint or formal notice of employee dissatisfaction related to adequacy of pay, job requirements, work conditions, other aspects of employment, or an alleged violation of a collective bargaining agreement." From these definitions, a concept can be raised that grievance is human belief or feelings against any unfairness or wrong deed and its formal expression are a complaint. After reviewing a thorough literature Opatha (2019) found eleven (11) key characteristics of grievance which are: dissatisfaction; complaint; dispute informality (verbal one), formality (written one), arising out of something relating to employment, individual nature (made individually), collective nature (made collectively), union involvement (made by the trade union), organized labor context (Its occurrence is in a context where employees have been organized into unions), real or imaginary matter. In this paper, a grievance is viewed as feelings or belief of any tenderer of being treated unfairly and complained or wish to complain against. And redress is viewed as the remedy to those grievances or complaints. However, the grievance-redress mechanism is discussed under the direct provisions of sections 29-30 of the PPA, 2006 which covers 'right to complain' \& 'lodging complain to the administrative authority, appeal \&, etc.' of any specific tenderer. In section 29 , p. 16, a grievance is however termed as, "If a person suffers or is likely to suffer loss or damage due to failure of a procuring entity to fulfill its obligations under this Act, he may complain against that procuring entity to the authority specified ${ }^{[16]}$.

It is preassumed that the procurement entity must disseminate procurement information through electronic medium i.e. Electronic Government Procurement (eGP). The present government, Awami League-led grand alliance, is on its way to keep pace with upgraded technologies by making the word 'digital' aboard. The party is doing so as part of their published election manifesto 'Charter of Change' with a vision 'Digital Bangladesh by 2021' also referred to as 'Vision 2021' on December 12 in 2008 for the $9^{\text {th }}$ parliamentary election held on December 29, 2008. The term 'Digitalization' does not have a single unified definition. The meaning of the term varies based on its uses. Emphasizing social life, Brennen and Kriess explained digitalization "as to how many domains of social life are restructured around digital communication and media infrastructures." [17] Thus, they defined the term 'digitalization' emphasizing social life- in other words, they described the term based on the way people interact and the transformation of that way of interacting. A transformation from reallife to virtual, snail mail to email, regular chat to virtual chat, etc. Valuing the business models rather than social interactions, it is explained that "the use of digital technologies to change a business model and provide new revenue and value-producing opportunities; it is the process of moving to a digital business" (https:// www.gartner.com/en/information-technology/glossary/ digitalization, accessed on 19 June 2019). On the other hand, focusing on how digitalization impacts people, it is advocated that the acquisition of digital skills is an 
advancement for individuals, industry, and organizations to attain success ${ }^{[18]}$. However, in this paper, digitalization can be referred to as the use of ICT infrastructures in ensuring transparency and accountability in public procurements. In other words, a transformation of the traditional working environment to an internet-based easily accessible one.

\section{Reform Initiatives Regarding E-Government Procurement}

There have been many reforms in the public sector for materializing the result-based management approach in the process of project implementation. For implementing reforms under result-based management, the GoB established Central Procurement Technical Unit (CPTU) under the Implementation, Monitoring, Evaluation Department (IMED) of the planning division and enacted procurement rules in 2003 with financial assistance from donors agencies including the World Bank and Asian Development Bank. The key objective was to evaluate and monitor the activities of the executive agencies of different government organizations that are responsible for discharging the responsibilities of public sector project preparation \& implementation. A secretary-headed division is IMED under which a director-general (hereafter DG) runs the CPTU. A pool of three directors and a system analyst operate the unit under the supervision of the DG. For e-GP, Monitoring \& Evaluation, there remains a dedicated pool comprising of a director, two deputy directors or similar rank, assistant maintenance engineer, assistant director, and an assistant programmer. A deputy director under whom a programmer \& a computer operator remains responsible for the operational activities of e-GP. A formal structure for GRM is absent in the organogram of CPTU (Appendix-A). Whereas, an assistant programmer/information analyst accumulate opinion received via 'opinion on e-GP' regarding the specified criterion only. The PPA, 2006 has 9 chapters and 73 sections while the PPR, 2008 is composed of 130 rules, 9 chapters, and 14 schedules covering the procurement procedures and have been amended due to requirements faced by the GoB several times ${ }^{[13]}$. To foster and ensure transparency, sections 6,7 , and 40 respectively, embody 'Opening Committee' 'Evaluation Committee' and 'Advertisement' where each committee consists of three members; a chairperson, a member, and a member secretary. These provisions prohibit a person to be a perverse one since multiple committees are formed. And by definition, the formation of these committees curbs the possibility of holding much power in a single arm. In the same way, to ensure accountability measures the PPA,
2006 has some specific provisions including sections 2930 of chapter three and section 64 of chapter seven. These provisions demonstrate complaints and appeal as well as professional misconducts, offenses, etc. By these sections, the PPA, 2006 brings a person close to his rights regarding grievances and discloses the chances of indictment against the officials. It is clearly stated that these sections are relatable to horizontal accountability and a proportionate to maintain checks and balance in this arena. However, those sections 29-30 of chapter three of the PPA, open up the door of grievance redress mechanism in this regard. The establishment of e-GP is a clear and successful implementation of section 65 of chapter 8 which induces the establishment of an electronic processing system to carry out the government procurement easily. And its guidelines are prepared under the provision of section 67 of the PPA, 2006 \& rule 128 of the PPR, 2008 which denotes "responsibilities of government regarding monitoring". Public procurement has two broad categories i.e. procurement for goods, works, etc., and procurement for intellectual \& professional services. Now, e-GP covers only the category of procurement for goods, works, etc.

The e-GP has been implemented by the CPTU of IMED, Ministry of Planning. It was done as part of a project titled PPRP II which was jointly financed by GoB and the World Bank. The project is comprised of four fundamental components (a) policy reformation and capacity development, (b) Firming up the better procure management procedure at sector level, (c) Familiarizing electronic-Government Procurement (e-GP) and (d) Organizational change in behavior, communication and social accountability ${ }^{[19]}$. It was assumed that the project would be public by eight years but the PPRP II took a year more. In final review, the World Bank bestowed the progress of the project with satisfactory words. At the end of the project, it is found that all the PDO have met the project end target and four of them exceeded the target. And it has been contributing to make a systematic change in the public procurement regime.

The implementation process of e-GP is sought to be in two phases: (a) e-tendering system, covering the whole process of tendering such as User registration, initiation of Annual Procurement Plan (APP), Instruction to Tenderers (ITT), sale of Tender Documents (TD), conducting an online pre-bid meeting, collection of bid security, bid submission, bid evaluation, negotiations, and contract awards. (b) e-contract management system (e-cms), covers comprehensive Contract Management processes such as submission of a work plan, defining milestones, tracking and monitoring progress, generating reports, performing quality checks, generation of running bills, 
vendor rating, and generation of completion certificate ${ }^{[20]}$. In 2008, the project PPRP II started but the GoB has introduced the e-GP system in 2011. Initially, three agencies Roads and Highways Division (RHD), LGED, and Bangladesh Water Development Board (BWDB) were the core agencies for implementation. Later, the Rural Electricity Board (REB) had stepped on the vessel. Presently, the e-Tendering System is launched as part of a pilot project and by the time it will be open to all public enterprises (hereafter PEs) of four Sectorial Agencies, namely BWDB, LGED, REB, and RHD. The CPTU under the Ministry of Planning has been given the right to manage the e-procurement process of all the agencies and also maintains e-GP along with these agencies. At present, 56 ministries, 39 divisions, and 117 organizations have registration on e-GP along with 22, 8, and 14748 PEs of those respectively. In the year 2017, a total of 97 tenderers/consultants, individual tenderers both national and international are registered with e-GP. 38 banks are now linked to e-GP for payments ${ }^{[18]}$. The process of e-GP has been kept simple and user-friendly. According to the rule, the tender notices are advertised on the electronic system and in the national dailies. A bidder with in-line certifications of to be procured items needs to $\log$ on to the e-GP website and place his bid for tender of his interest. But the tenderers need to be registered on the e-GP portal first.

\section{Results and Discussion}

Procuring entities are good sources of information to determine the cogency of this study. A glance on the Table 1 can clarify the present status of works of the e-GP in effect. As of the mentioned date since the implementation of e-GP under CPTU, 56 ministries have invited a total of 25789 tenders of which 18780 is being processed and 6692 have been awarded through the system. On the other hand, both 39 divisions and 117 organizations have invited a total of 15054 tenders and 25789 tenders respectively of which both of them awarded 3779 and 6692 tenders respectively to the registered tenderers to be procured. These numbers are justifiable in the event of the efficiency of the newly administered e-GP system. Where the registered tenderers shared their satisfactory words regarding the hassle-free, systematic, and fast process, they come up within. Unlikely, a few numbers of tenderers expressed their views as they are pretty unknown of the process since they are unable to have a look at the tender awarding method. It seems unfair to them as it has no open tendering method like the previously used 'an open lottery' process. Here, it strikes again the necessity of GRM in terms of e-GP.
Table 1. The present status of public works of the e-GP in effect

\begin{tabular}{cccc}
\hline & $\begin{array}{c}\text { No. of Tenders/ } \\
\text { Proposals } \\
\text { Invited }\end{array}$ & $\begin{array}{c}\text { No. of Tenders/ } \\
\text { Proposals being } \\
\text { Processed }\end{array}$ & $\begin{array}{c}\text { No. of } \\
\text { Contracts } \\
\text { Awarded }\end{array}$ \\
\hline Ministry : & 25789 & 18780 & 6692 \\
Division : & 15054 & 11111 & 3779 \\
Organization : & 25789 & 18780 & 6692 \\
\hline
\end{tabular}

Source: (www.eprocure.gov.bd accessed on 19 June, 2019)

The grievance redress mechanism of government procurement is handled by the CPTU. However, each authority of procuring entity is closely connected in addressing the grievances as per the articles and rules of the PPA, 2006 and PPR, 2008 respectively. In LGED, procuring entities are categorized with different levels. Chief Engineer tops the ladder being the Head of Procuring Entity (HOPE). The others remain significant in procuring as Project Director, Executive Engineer, and Upazila Engineer respectively. In the project approving authority ladder, LGED has six more authorities to sanction procurement. These are the Ministry of LGRD \& C especially the Local Government Division (LGD), the Cabinet Committee for Government Purchase (CCGP), HOPE, and three types of project directors i.e. PD-A, PD-B, \& PD-C. Each of the authorities has limitations in terms of fund authorization. CCGP can authorize more than 100 crores contract value for the works and goods procurement. Ministry can authorize more than 30 crores but less than 100 crores. At the second tier, HOPE can approve up to 30 crores and three types of project directors can approve below 20 crores work contract value. Chief Engineer of LGED delegated power to district Executive Engineer to approve contract ${ }^{[13]}$. LGED has finalized 67,469 tenders via e-GP since $2011^{[18]}$. Though e-GP has been initiated, there is no particular module for electronic or digital GRM to submit complaints. There prevails an opinion tab and that is worthy of reading only not for writing any opinion accordingly. The traditional process is followed in the GRM system. Firstly, if someone wishes to submit a complaint against, he has to follow the traditional procedure of complaint lodging. Since CPTU follows the rules of the PPR, 2008 in solving the disputes, it constitutes the mechanism likely the following. GRM as per the PPR, 2008 can be divided into two parts for the convenience of discussion. These are (a) Submission of Complaints, (b) Disposal of appeal by Review Panel.

(a) Submission of Complaints: According to rule 57 of the PPR, 2008 there remain four tiers in the initial complaint submission ladder. Procuring Entity, HOPE, Secretary of the Ministry, and the Review panel 
are the steps of the ladder in complaint submission. A tenderer with his concerned grievance initially lodges his complaint to the Procuring Entity (PE) Officer (PD, LD, $\mathrm{PM}, \mathrm{PO}$ ) assigned for the procurement who issued tender or proposal document. The tenderer should receive a response within 7 working days. But if he does not get any response or poses a dissatisfaction with the response, he can submit a complaint to the HOPE. The HOPE should respond in-between 3 working days. If the tenderer holds the same dissatisfaction, then he has the right to complain to the Secretary of the ministry. The Secretary's response should come out within 7 working days. If the tenderer has previous feelings and thinks he has not received the desired or rightful justice yet, he may pursue an appeal through the Review Panel. A person can pursue an appeal through a review panel only when he has left no other options of complaining to the administrative authority under rule 57 of the PPR, 2008. The review panel shall issue a written decision in-between a maximum of 12 working days.

(b) Disposal of Appeal by the Panel: After receiving the complaint through CPTU, the review panel recommends the procuring entity suspend the issuance of notification award until the panel makes its decision. The Review Panel shall issue a written decision to the plaintiff providing a copy to the secretary of the concerned ministry or division, the CPTU, and the procuring entity. The verdict can be the rejection of the appeal, if so, the panel may state the reasons behind it, may suggest the procuring entity to continue procurement proceedings. Otherwise, the panel may advise the parties to act accordingly stating the rules or principles that govern the subject matter. The panel has the jurisdiction to recommend remedial measures if it finds that the procuring entity acted in contradiction to its obligations under the rules. Or the panel can recommend a compensation package by that procuring entity for costs incurred by the plaintiff. The expenses include the cost of preparing tender documents, all types of legal fees, and other expenses incurred in lodging the complaint including the security deposit. The review panel shall decide upon the majorities' opinion. Decisions taken by the procuring entity or the review panel will be part of the recording of procurement proceedings as per the PPR, 2008 \& PPA, 2006.

Secondly, the Table 2 shows the differences in addressing complaints before the implementation of e-GP and the after. It shows positivity and up-gradation in addressing grievances. Whereas the method is still traditional, the initiation of e-GP ensures the disclosure of information. Table 2 is the representation of year-wise decisions given by the review panel of CPTU, it includes procuring entities v. tenderers cases. However, data shows that after the enactment of the PPA, 2006 and the PPR, 2008, the higher number of cases has been raised whereas it was lower in previous years. Though the number of decisions in favor of PEs is outwardly high comparing the number of applicants. Previously, there was no such mechanism of addressing grievances in a proper way within the LGED.

Table 2. Digitalization matters for grievance redress mechanism: An analysis

\begin{tabular}{cccc}
\hline Year & Decisions in Favor & Total Decisions \\
\hline 2005 & PE & Applicant & \\
2006 & 0 & 1 & 1 \\
2007 & 6 & 4 & 10 \\
2008 & 3 & 4 & 7 \\
2009 & 7 & 4 & 11 \\
2010 & 13 & 13 & 26 \\
2011 & 13 & 12 & 25 \\
2012 & 14 & 14 & 28 \\
2013 & 20 & 21 & 41 \\
2014 & 23 & 10 & 33 \\
2015 & 27 & 18 & 45 \\
2016 & 37 & 20 & 57 \\
2017 & 28 & 37 & 65 \\
2018 & 49 & 36 & 85 \\
Total & 29 & 18 & 47 \\
& $\mathbf{2 6 9}$ & $\mathbf{2 1 2}$ & 481 \\
\hline & 55.93 & 44.07 & 100.00 \\
\hline
\end{tabular}

Source: https://cptu.gov.bd accessed on 10 July 2019

Thirdly, interview data with tenderers (10) revealed that they had a positive perception about the traditional "lottery method-" the tender awarding process. They argued that the process was more transparent to them while the newer technique makes a vague $\&$ ambivalent feeling amongst them. Their prior experience with the LGED and its staffers creates such feelings, they disclosed. They expressed their opinion that they did not know how the lottery system in the e-GP process was.

Despite these rules of grievance redress mechanism and an electronic procurement system, the GRM procedures remain traditional. According to the CPTU, it is called the complaints handling mechanism on which the above discussion is made. And it is found that the GRM regarding e-GP should be upgraded to 
a top-notch digitalized process. Following an array of changes country's procurement system has got its desired transparent procurement process. However, it is found that obstruction that likely to be happened previously, with the up-gradation to e-GP did not work out.

Fourthly, data revealed that the political or other muscleman practices have lost their uses since tender schedules are available in bank branches ${ }^{[21]}$. These schedules can be collected from any branches of registered banks, as the opening of tender information is disseminated over the CPTU website. Nevertheless, the grievance redress mechanism remains manual in this era of changes. The CPTU has only an e-system of providing judgment and appeal status and publishes a brief judgment also. Though it publishes these notices and judgments, it has no way of addressing grievances. Therefore, it is worthy of saying that digitalization does not matter in grievance redress mechanism.

\section{Conclusions}

Socio-economic development in a country like Bangladesh goes through ups and downs due to political instability and lack of awareness among its people. The procurement act is called the legal means of ensuring accountability and transparency in government purchasing. It helps bring efficiency and effectiveness in the service delivery process. Implementation of e-GP made the country's procurement system easier than that of the previous. Before the implementation of the e-GP, it caused harm to the people who wished to submit tenders due to political pressure and muscle power practices. Nepotism, patron-client relationship, etc. was seen in the public procurement processes ${ }^{[21]}$. However, the everexpected act and the implementation of e-GP reduces these phenomena ${ }^{[8]}$. The findings of the paper indicate that the grievance redress mechanism remains manual while the other mechanism of the procurement process is digitalized. There is some changes-some traditional working mechanism got the attention of digitalization i. e. brief judgment, judgment and appeal status, etc. Moreover, the procurement process in being digital brings benefits to the tenderers and stakeholders in this regard.

\section{Conflict of Interest}

The authors declared no potential conflicts of interest with respect to the research, authorship, and/or publication of this article.

\section{References}

[1] McCourt, W., 2013. Models of Public Service Re- form: A Problem-Solving Approach. Policy Research Working Paper, No. 6428. Washington D.C: The World Bank.

[2] Chowdhury, S., Panday, P.K., 2018a. Strengthening local governance in Bangladesh: Reforms, participation and accountability. New York, the USA: Springer.

[3] Obaidullah, A.T.M., 1999. Bangladesh public administration: Study of major reforms, constraints and strategies. Academic Press and Publishers Ltd. Dhaka.

[4] Finan, W.F., Dean, A.L., 1957. Procedure for preparation and implementation of administrative reforms, International Review of Administrative Sciences. 23(4), 438.

[5] Lane, J., 2009. State Management: An Enquiry into Models of Public Administration \& Management, Routledge, USA and Canada.

[6] Djankov, S., 2016. The Happiness Gap in Eastern Europe. Journal of Comparative Economics. 44(1), 108-124.

[7] Hoque, R., 2010. Public Procurement Law in Bangladesh: From Bureaucratisation to Accountability. NUJS LAW REVIEW. 3(3), 281-29.

[8] Mahmood, S.A.I., 2010. Public procurement and corruption in Bangladesh: confronting the challenges and opportunities. Journal of public administration and policy research. 2(6), 103-111.

[9] Ahmed, F.U., 2013. Application of Result Based Management in the Public Sector Projects: A study on the Readiness Situation of Bangladesh. Unpublished PhD Thesis, Institute of Bangladesh Studies (IBS), University of Rajshahi, Bangladesh.

[10] Islam, M.A., Akhter, S., Islam, M., 2018. Health Financing in Bangladesh: Why Changes in Public Financial Management Rules Will Be Important, Health Systems \& Reform. 4(2), 65-68. DOI: https://doi.org/10.1080/23288604.2018.1442650

[11] Kamruzzaman, A., 2015. Measuring Procurement Performance of LGED and RHD Based on Key Performance Indicators. BRAC Institute of Governance and Development, BRAC University.

[12] Islam, M.S., 2011. Improving Transparency in Public Procurement in Bangladesh: Use of Right to Information and Whistleblower's Protection laws at sub national level. paper presented in the USA.

[13] Sarker, T.K., 2018. Implementing e-GP in Bangladesh: A Perspective of Works Procurement in LGED. BRAC Institute of Governance and Development, BRAC University.

[14] Opatha, H.H.D.N.P., 2019. Defining a Grievance: A Theoretical Examination of An Old Issue, Sri Lankan Journal of Human Resource Management. 9(1), 21- 
41.

[15] Glueck, W.F., 1979. Foundations of Personnel, Texas: Business Publications Inc.

[16] MoP, 2008. Public Procurement Act (PPA) (2006), Central Procurement Technical Unit (CPTU), Implementation Monitoring and Evaluation Division (IMED), Ministry of Planning (MoP), Government of the People's Republic of Bangladesh. Bangladesh Gazette, dated: 27 January 2008.

[17] Brennen, J.S., Kreiss, D., 2016. Digitalization. In JensenK. B.CraigR. T.PooleyJ. D.RothenbuhlerE. W. (Eds.), The International Encyclopedia of Communication Theory and Philosophy (pp. 556-566). Wiley Blackwell. 10.1002/9781118766804.wbiect111.

[18] Muro, M., et al., 2017. Digitalization and the American workforce. Washington, DC. Metropolitan
Policy Program Brookings Institution. Retrieved from https://www.brookings.edu/wp-content/uploads/2017/11/mpp_2017nov15_digitalization_full_ report.pdf

[19] Abdallah, W., 2016. Benefits and Costs of Introducing e-Procurement in Bangladesh. Copenhagen Consensus Center.

[20] National e-Government Procurement (e-GP) portal of the Government of the People's Republic of Bangladesh, http://www.eprocure.gov.bd (Retrieved on 19 June, 2019).

[21] Ahmed, H., 2018. e- Procurement and transparency in public sector: A case of Local Government Engineering Department (LGED). BRAC Institute of Governance and Development, BRAC University.

\section{Appendix-A}

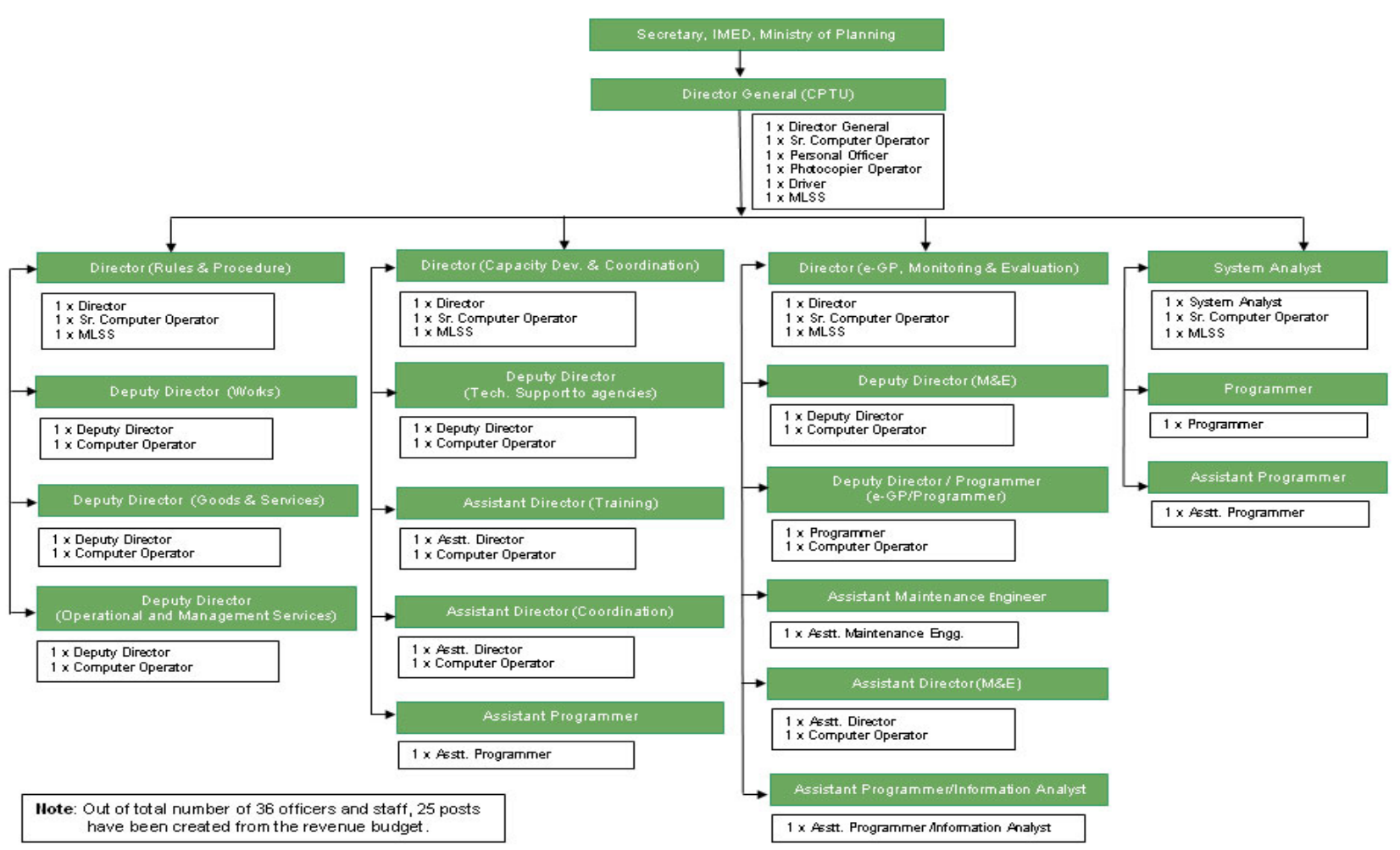

Figure 1. Organogram of Central Procurement Technical Unit

Source: https://cptu.gov.bd/about-cptu/organogram.html (accessed on 10th October, 2021) 